\title{
BEHAVIOUR OF 3D RC FRAMES WITH MASONRY INFILL UNDER EARTHQUAKE LOADS- AN ANALYTICAL STUDY USING E-TABS
}

\author{
Arulmozhi. $\mathbf{N}^{1}$, Srinivasan. $\mathbf{R}^{2}$, Suresh Babu. $\mathbf{S}^{3}$, Jegidha.K.J ${ }^{4}$ \\ ${ }^{I} P G$ Scholor, Department of Civil Engineering, Adhiyamaan College of Engineering, Hosur \\ ${ }^{2}$ Assistant Professor, Department of Civil Engineering, Adhiyamaan College of Engineering, Hosur \\ ${ }^{3} H O D$, Department of Civil Engineering, Adhiyamaan College of Engineering, Hosur \\ ${ }^{4}$ Assistant Professor, Department of Civil Engineering, Adhiyamaan College of Engineering, Hosur
}

\begin{abstract}
Moderate and astringent earthquakes have struck different places in the world, causing rigorous damage to reinforced concrete structures. The bond between the structural elements and masonry in-fills of the building is habitually effected by Earthquake. The voids between horizontal and vertical resisting elements of the building frame is filled by Masonry in-fills. An infill wall enhances considerably the strength and rigidity of the structure. It has apperceived that frames with in-fills have more vigor and rigidity compared to the bare frames Hence this study is about the demeanor of $3 D$-RC frames with and without masonry in-fills utilizing E-TABS. parameters were studied like displacement, lateral load distribution, stiffness and overturning moment of the frames and it is concluded that, the in-fill walls are needed to be considered while designing phase of the structures.
\end{abstract}

Keywords: Earthquake load, 3D RC Frame, Masonry In-Fill

\section{INTRODUCTION}

The earthquake is a phenomenon that releases high amount of energy in a short time through the earth. Structures designed to resist moderate and frequently occurring earthquakes must have ample stiffness and strength, to control deflection and avert any possible collapse. In other words, a structure not only should dissipate a considerable amount of imported energy by ductile demeanor, but additionally it should be able to control the deformations and transfer the force to substratum through enough lateral stiffness in ground kineticism From the observations of damages of the past earthquakes, it is hard to digest the loss of greater number of human lives and to the properties. So this is due to the lack of proper design and understanding construction technique among both public and engineering domain. The buildings, which had already been constructed is susceptible to face more seismic risk, due to the increased seismic vulnerability, hence proper evaluation of the building against seismic hazards is absolutely necessary.

The rapid industrialization and increase in population have called for optimum use of scarce land due to which multistorey building have become inevitable. Apart from dead and live loads, the structures have to withstand lateral forces. Under the action of natural wind and earthquake a tall building will be continually buffeted by gusts and other dynamic forces. Masonry infill walls are frequently utilized as interior partitions and exterior walls in low or middle elevate RC buildings. The infill walls are conventionally treated as non-structural elements and they are ignored in analytical models In the design and assessment of buildings because they are surmised to be propitious to the structural replications. Ergo their influences on the structural replication are generally ignored. When the boundary frame of the structure when it is subjected to ground forms of kineticism their stiffness and strength are not tiny. This interaction may or may not be salutary to the performance of the structure.

In developing countries, Most of the reinforced concrete (RC) frame buildings are in-filled with masonry walls. Experience during the past earthquakes has demonstrated the benign effects as well as the ill-effects of the presence of infill masonry walls. In least two moderate earth quake (enormity 6.0 to 6.5 and maximum intensity 7 on MM scale). In India, RC frame building with brick masonry infills have shown excellent performance even though most such buildings were not designed and detailed for seismic replication. From the extensive review of literature carried out, it has been found that no analytical study on three-bay, multi-storey R.C.C frame subjected to lateral loading has been done so far. In this research analytical study was carried out on a three bay, multi storey R.C frame with different locations and percentage of masonry in-fills. The load points were located at first storey level.

\subsection{Analytical Model:}

A typical multi-storey residential building, with three bays in longitudinal as well as in transverse direction is considered for study as shown in fig 1 . The grade of concrete used is M20 and steel is fe415. As per IS 456:200, The thickness of slab and masonry in-fill is $150 \mathrm{~mm}$ and $230 \mathrm{~mm}$ respectively. The live load on roof and floor finish are taken to be $3 \mathrm{kN} / \mathrm{m}^{2}$ and $1 \mathrm{kN} / \mathrm{m}^{2}$. The size of beam is $230 \times 450 \mathrm{~mm}$ and size of column is $230 \times 600 \mathrm{~mm}$. The building is considered to be sited in IV zone with medium soil setting. 


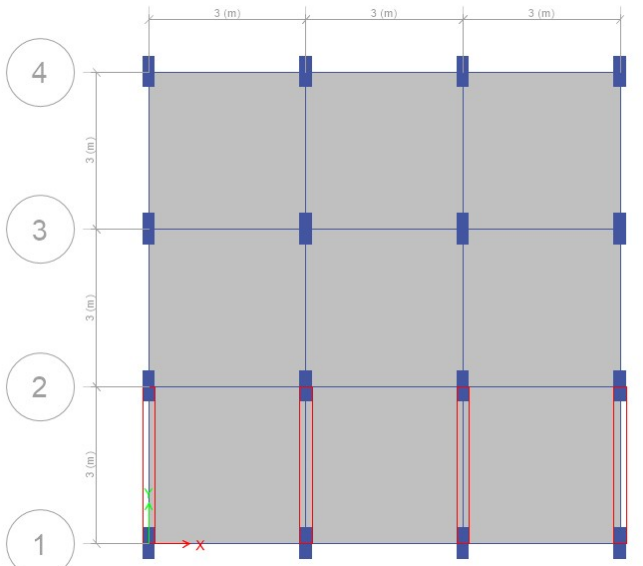

Fig(1). Plan of frame

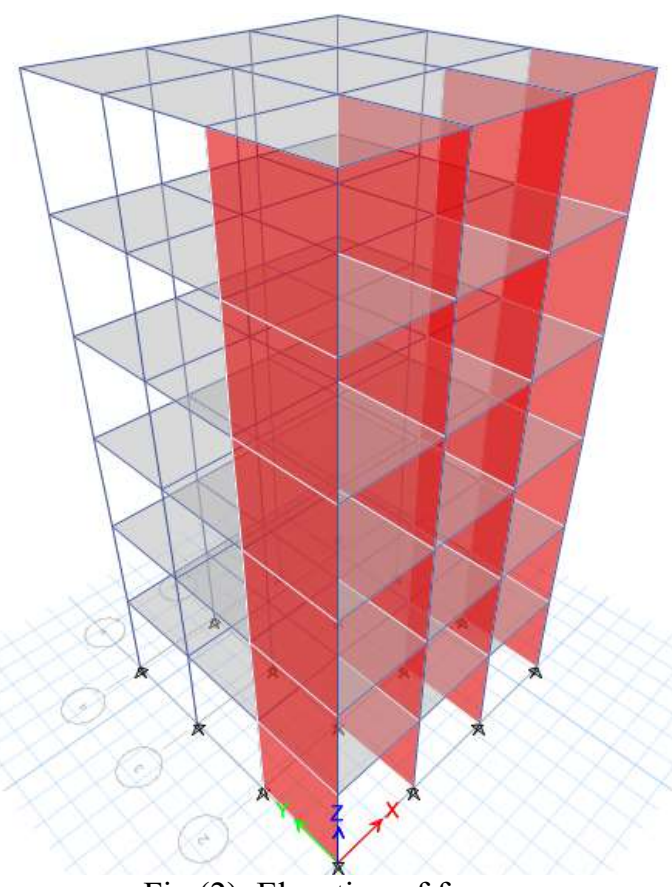

Fig (2). Elevation of frame

\section{METHODOLOGY OF THE PRESENT WORK:}

In this study, response spectrum analysis is used to determine earthquake response of the structure using E-tabs software. The analysis is performed on three cases: $\mathrm{G}+5$, $\mathrm{G}+10, \mathrm{G}+20$ with different in-fill wall configurations. The frame is premeditated as per prevailing practice in India. Seismic loads are predictable as per IS 1893 (2002).The dead and live loads are calculated using IS 875 Part 1 (1987) and lateral loads are calculated as per IS 1893(2002). . The seismic parameters such storey displacement, lateral load distribution was calculated for the below models.

Three cases were considered for the analysis of frames with various infill wall configurations at various percentages.

\section{Case (1). $G+5$}

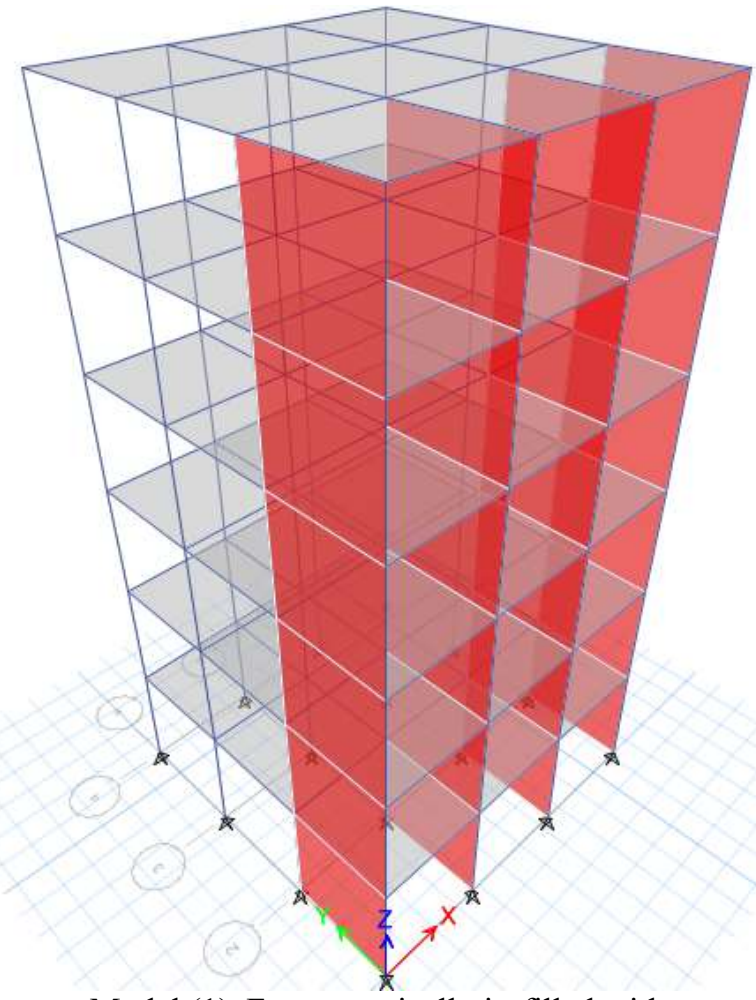

Model (1). Frame vertically in-filled with masonry walls in a single bay

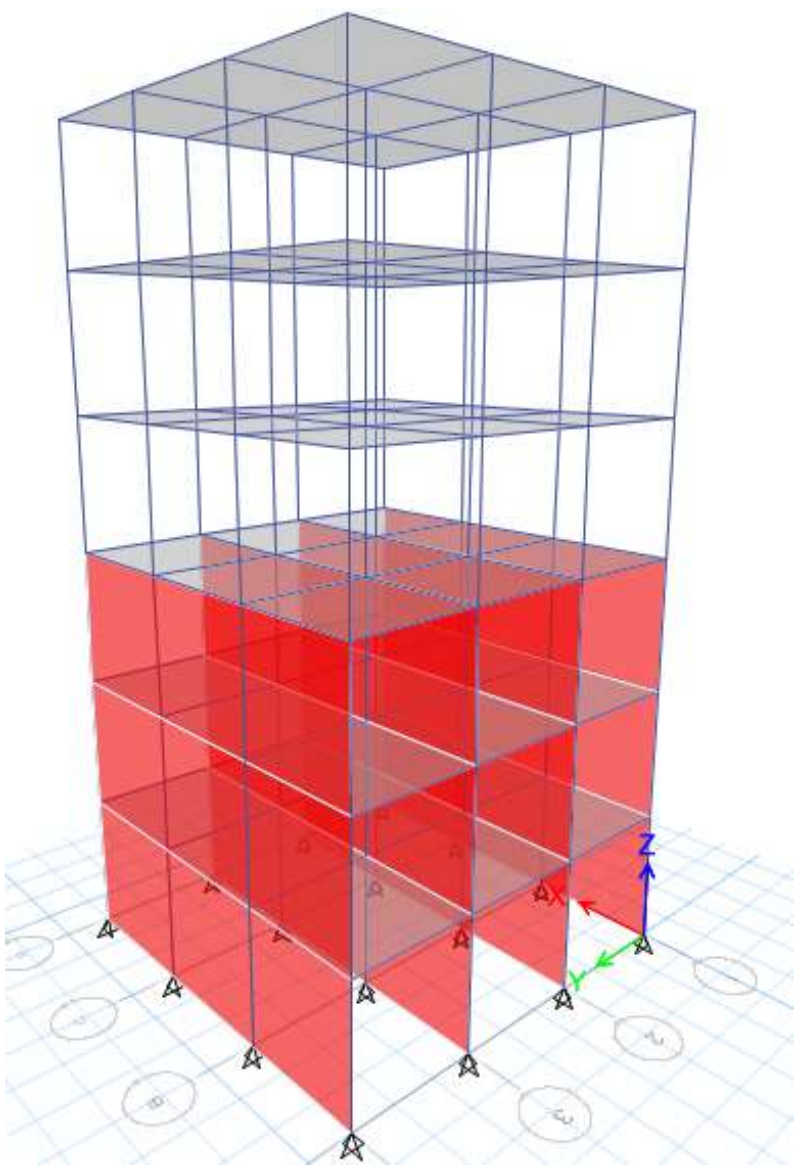

Model (2). 50\% of Frame in-filled with masonry walls in all three bays. 


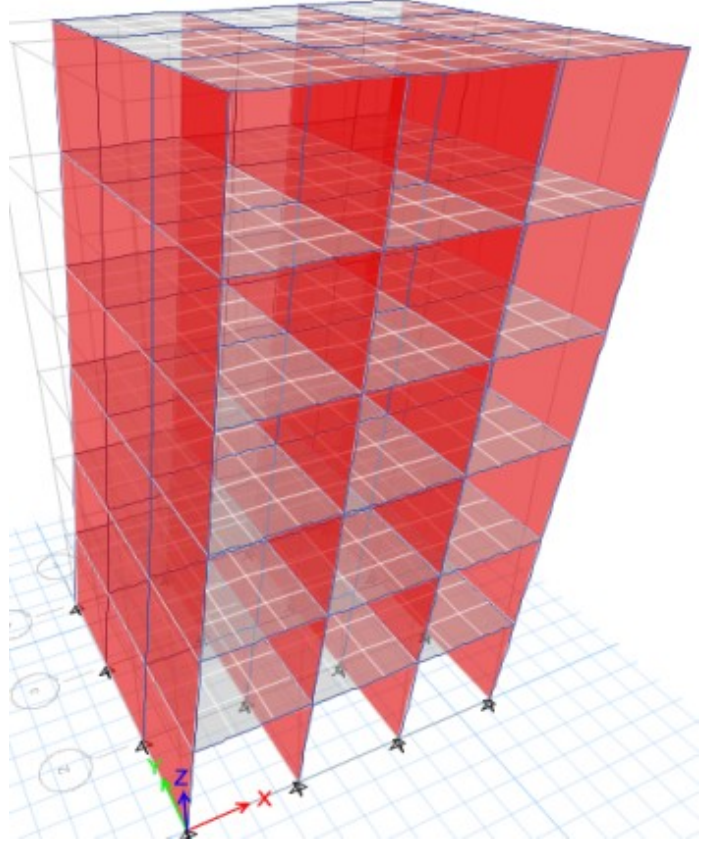

Model (3). $100 \%$ of frame in-filled with masonry walls in all three bays.

\section{Case (2). G+10}

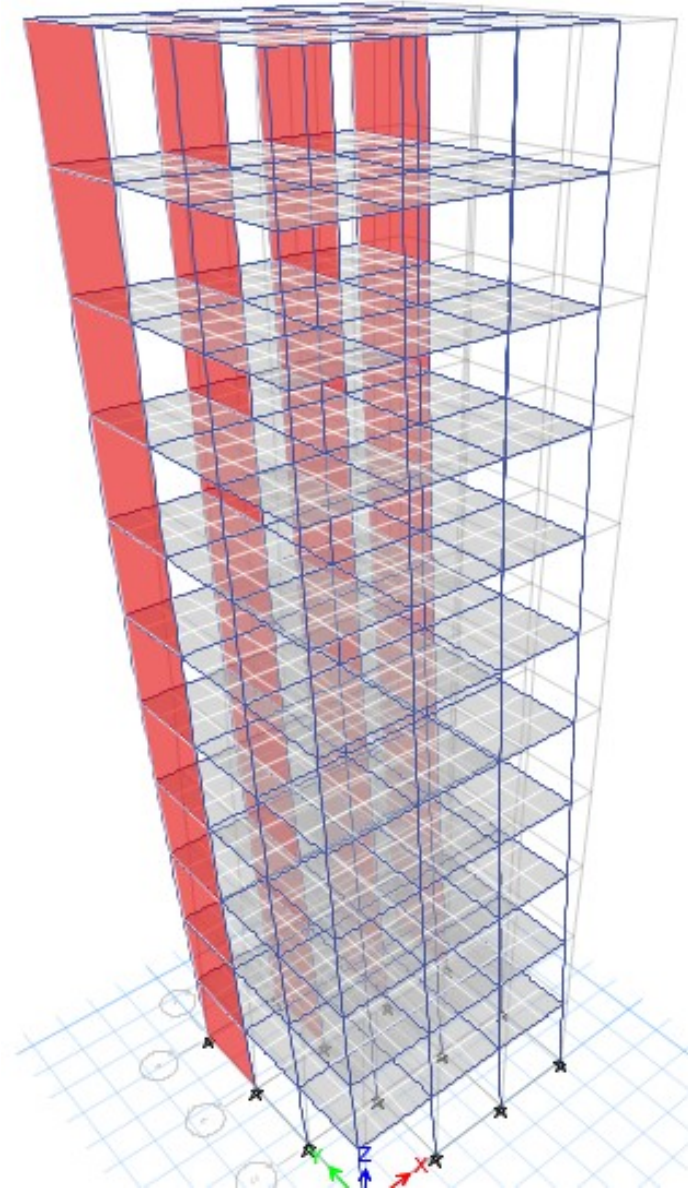

Model(1). Frame vertically in-filled with masonry walls in a single bay along a $\mathrm{X}$ direction.

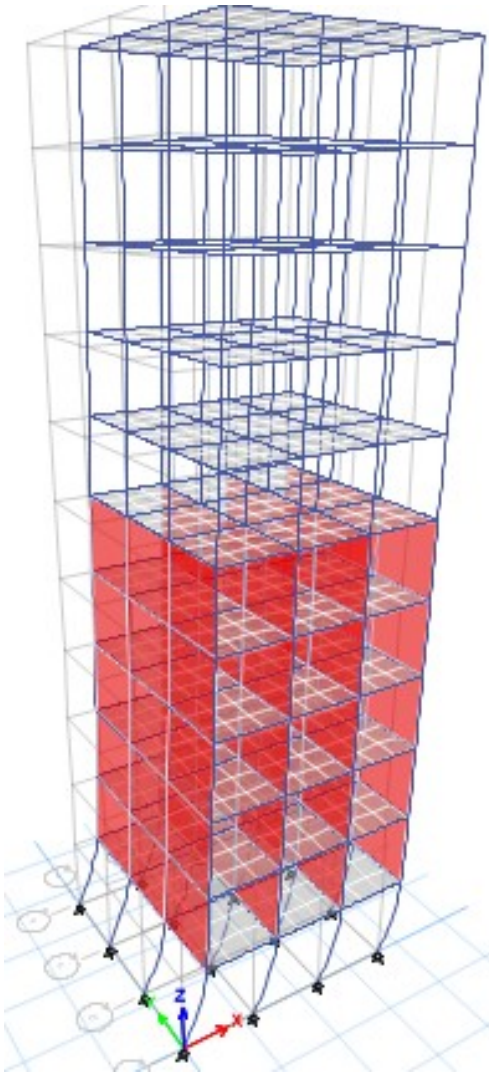

Model (2). 50\% of Frame in-filled with masonry walls in all three bays at bottom stories

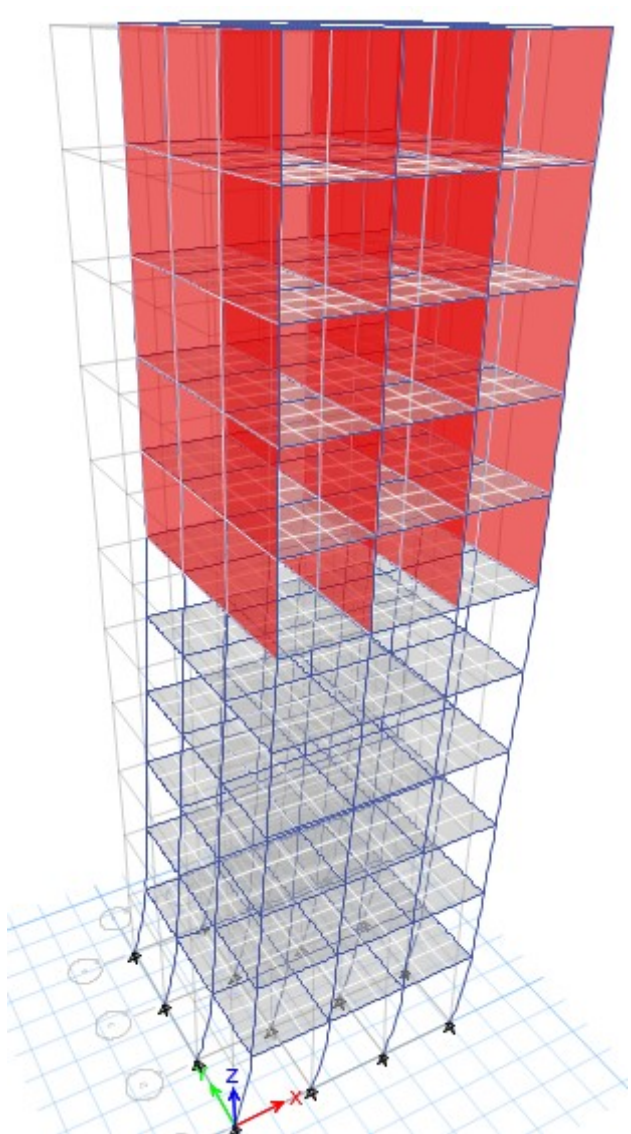

Model(3). Frames in-filled with masonry walls in all three bays at top stories 


\section{Case (3). G+20}

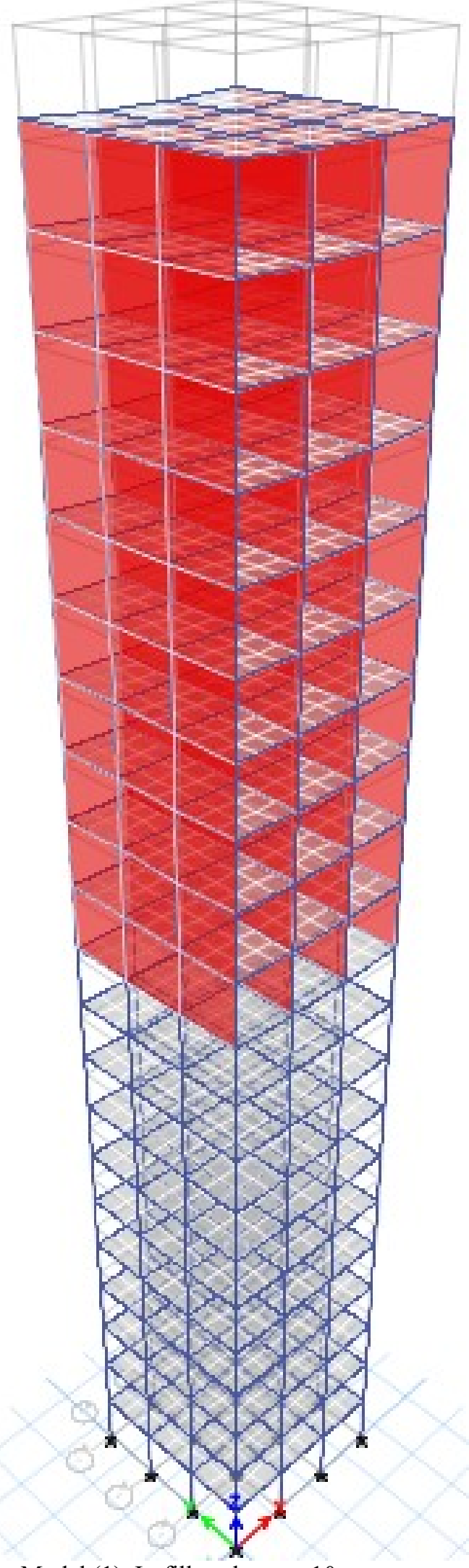

Model (1). In-fills at bottom 10 storeys

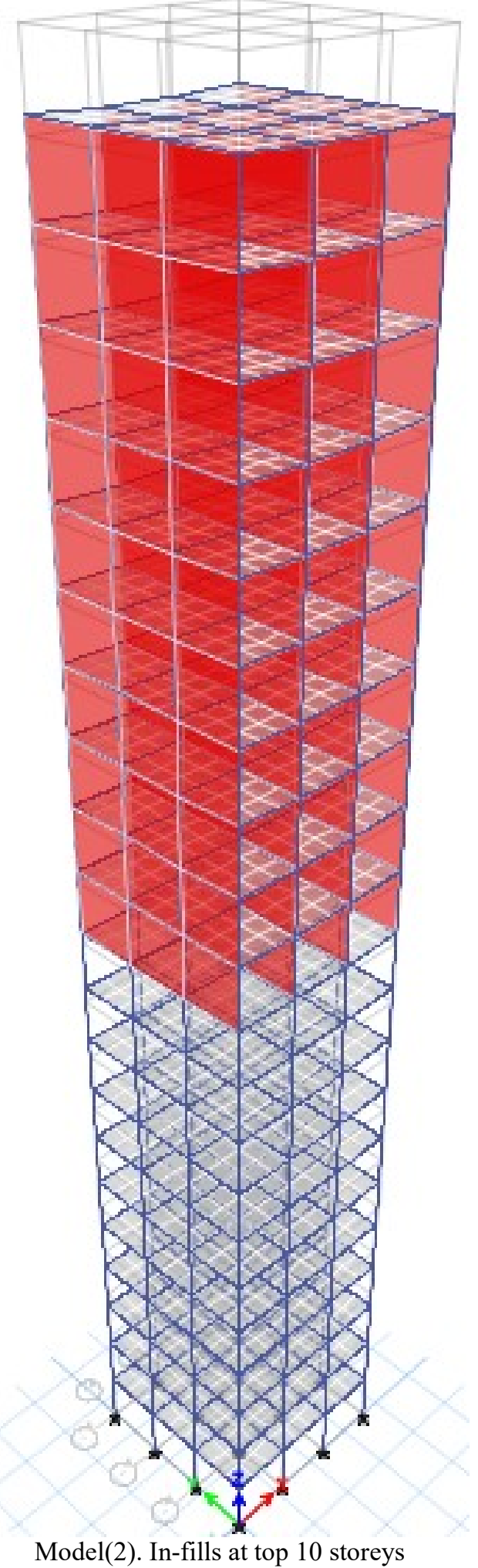

\section{RESULTS AND DISCUSSIONS:}

The performance of fames with various percentage of masonry infills for the specified models are alalysed using E-tabs software. Those results have been compared based on the parameters like, displacement, lateral load distribution, overturning moment and stiffness. The graphs obtained from software analysis are shown in fig 3 to fig 14 . 


\section{Case(i): $\mathbf{G}+5$}

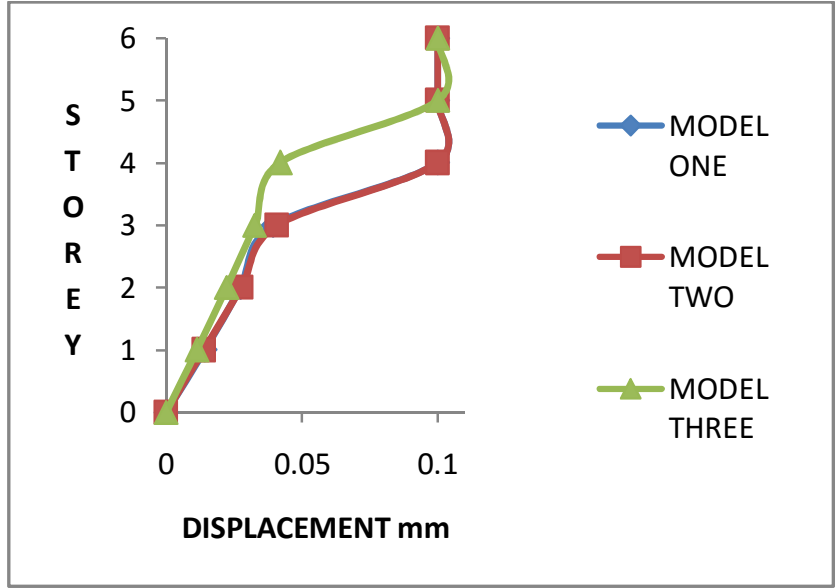

Fig (3)

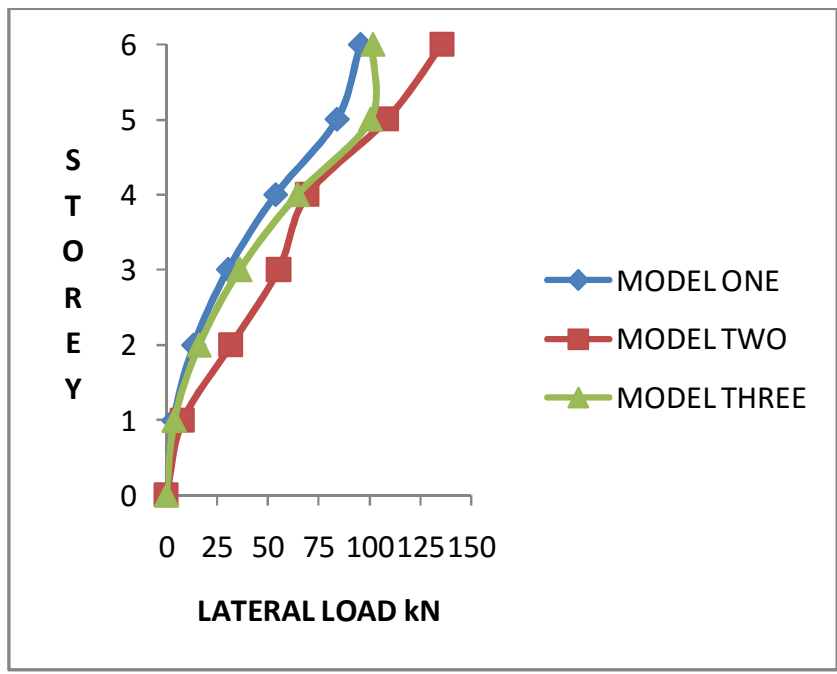

Fig (4)

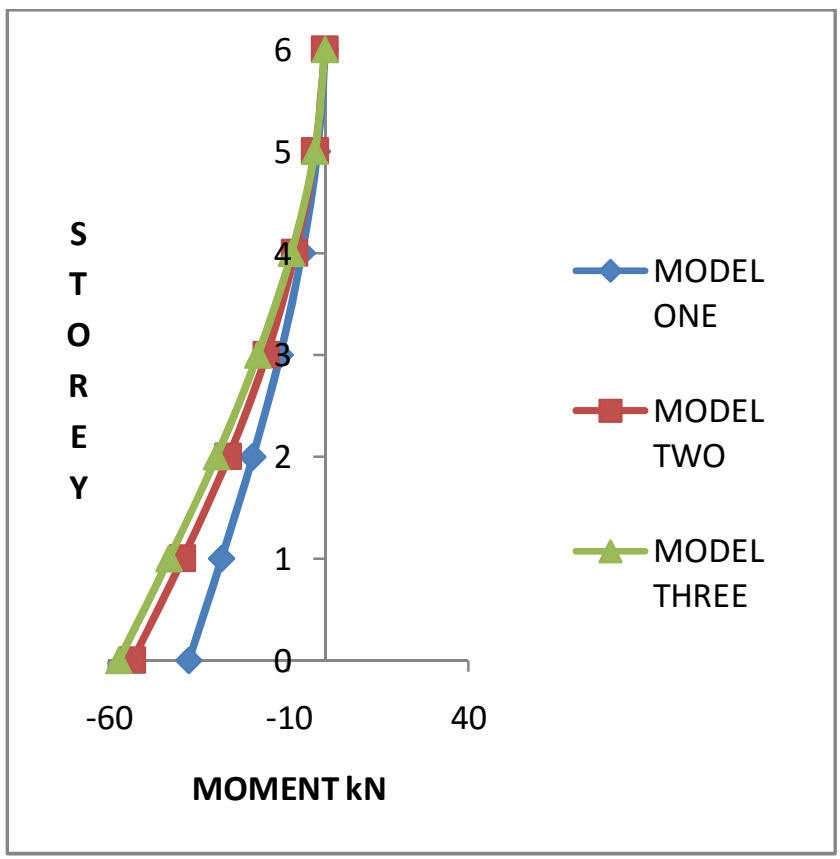

Fig (5)

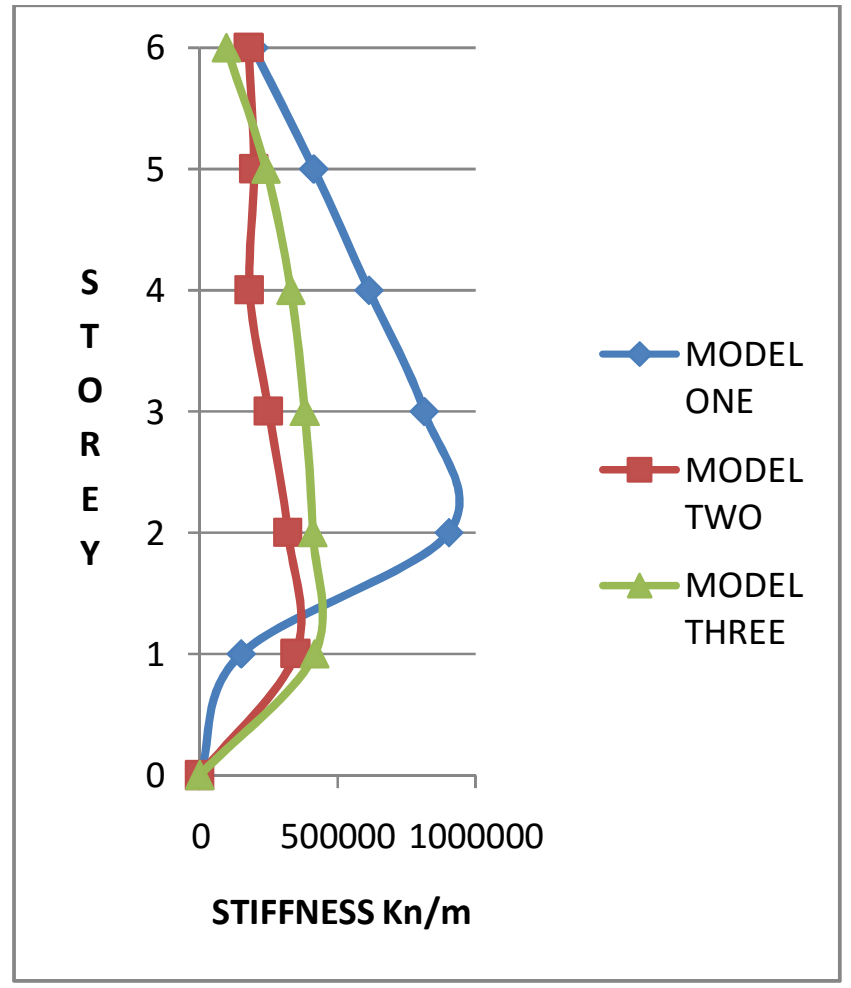

Fig (6)

\section{Case (ii: $\mathbf{G}+\mathbf{1 0}$}

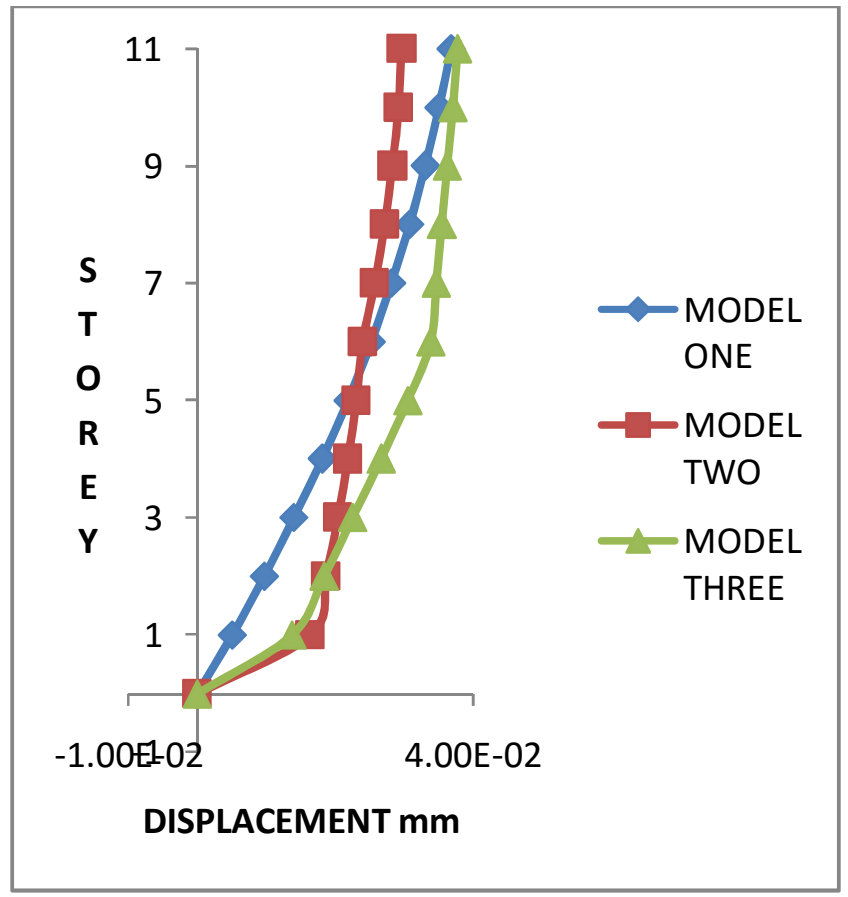

Fig (7) 


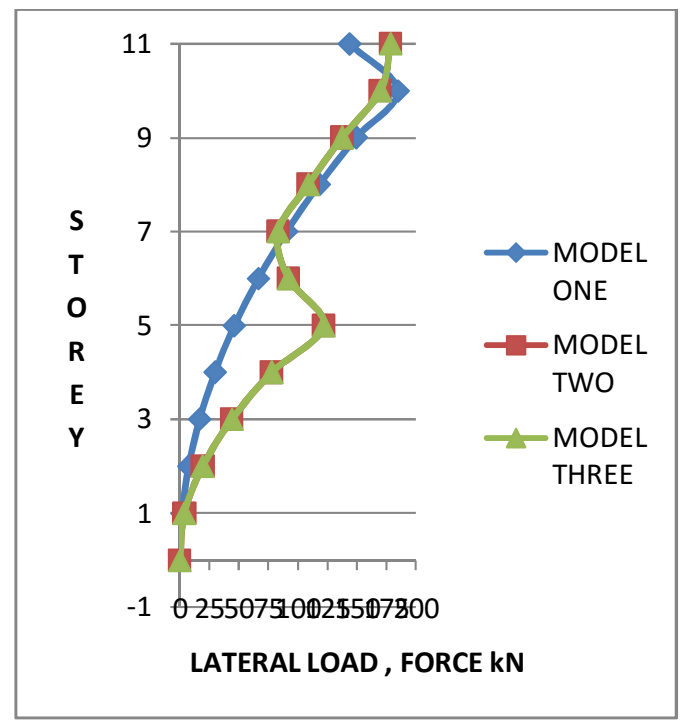

Fig (8)

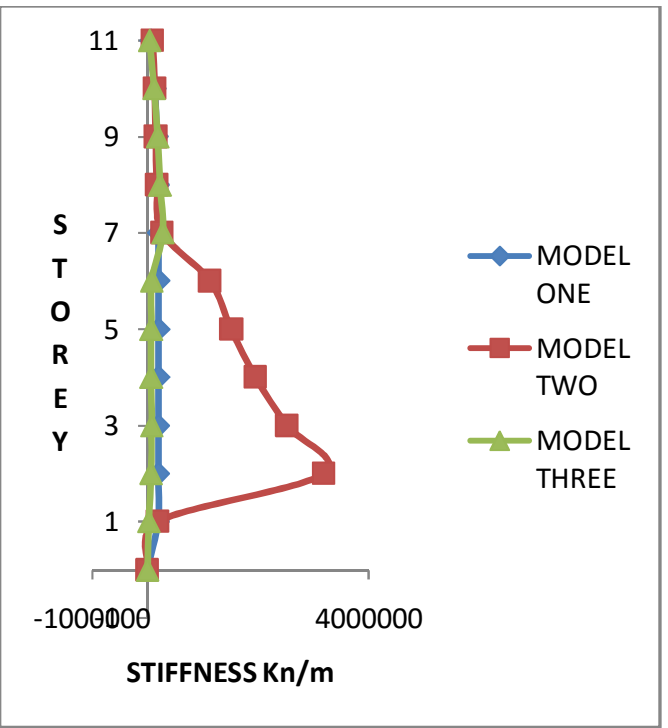

Fig (9)

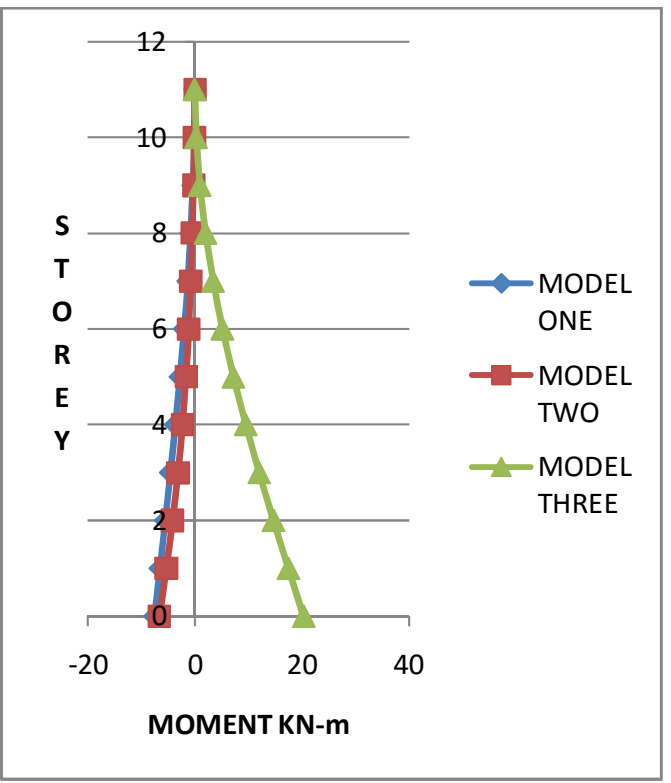

Fig (10)

\section{Case (iii): $\mathbf{G}+\mathbf{2 0}$}

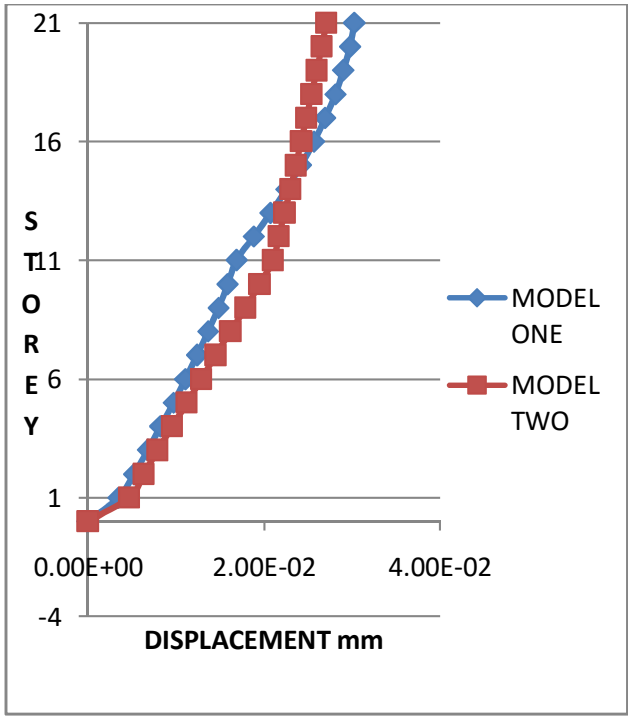

Fig (11)

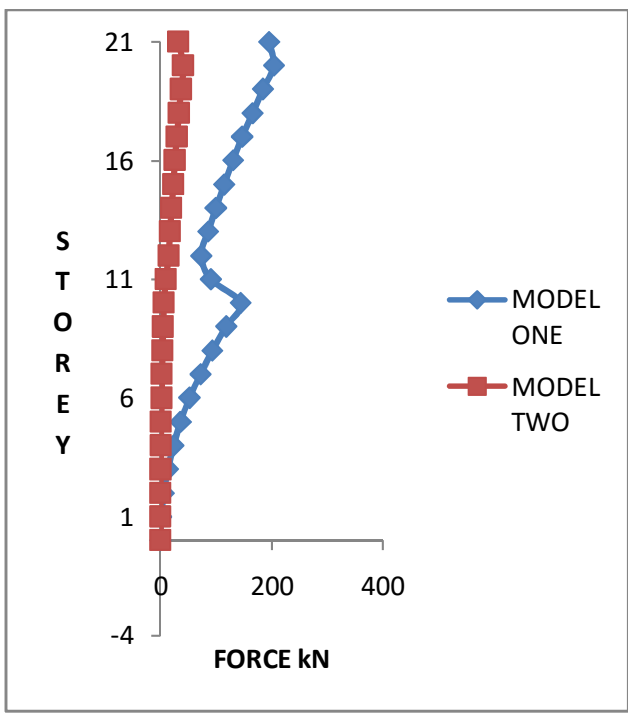

Fig (12)

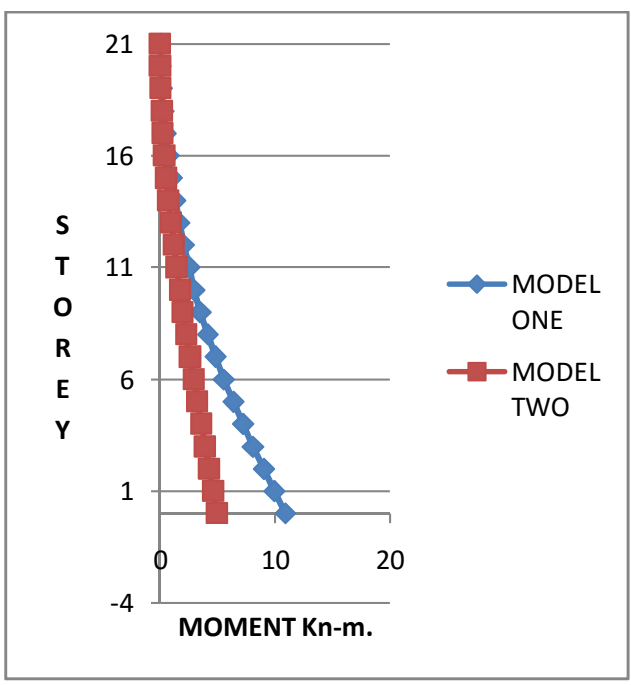

Fig (13) 


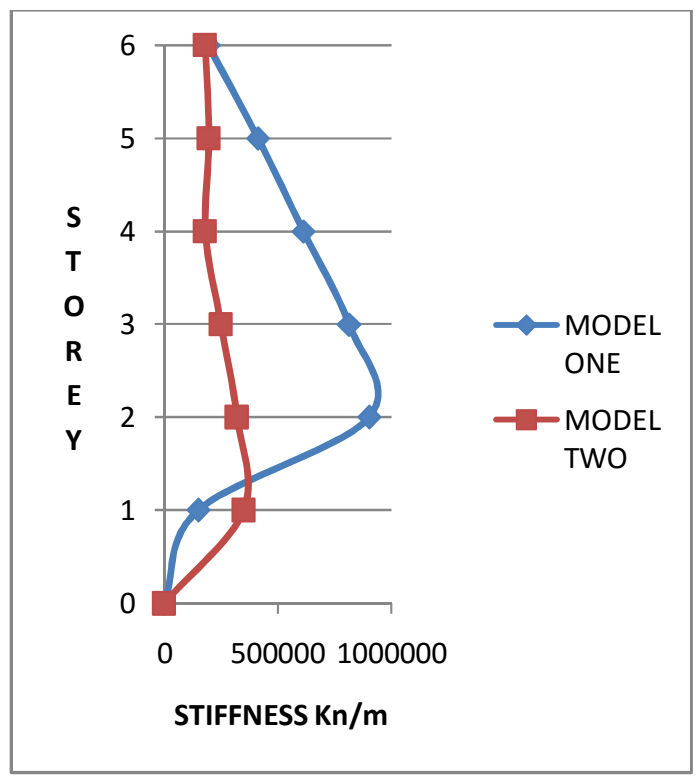

Fig (14)

Fig (3 to 14). shows the displacement, lateral load, stiffness and overturning moment of the frame

Table (1) and (2). Comparative analysis of all 3 cases

\begin{tabular}{|l|l|l|l|l|}
\hline Cases & Model & $\begin{array}{l}\text { Displac } \\
\text { ement } \\
\text { mm }\end{array}$ & $\begin{array}{l}\text { Over } \\
\text { turning } \\
\text { moment } \\
\text { kN-m }\end{array}$ & $\begin{array}{l}\text { Storey } \\
\text { shear, } \\
\text { kN }\end{array}$ \\
\hline $\begin{array}{l}\text { Case (i) } \\
\text { G+5 }\end{array}$ & Model one & 70 & 18.5 & 0.30 \\
\cline { 2 - 5 } & Model two & 73 & 41 & 0.81 \\
\cline { 2 - 5 } & Model three & 48 & 32 & 0.58 \\
\hline \multirow{2}{*}{$\begin{array}{l}\text { Gase (ii) } \\
\text { G+10 }\end{array}$} & Model one & 37 & 20.2 & 0.96 \\
\cline { 2 - 5 } & Model two & 16 & 6.40 & 4.40 \\
\cline { 2 - 5 } & Model three & 13 & 7.20 & 3.40 \\
\hline $\begin{array}{l}\text { Case (iii) } \\
\text { G+20 }\end{array}$ & Model one & 30 & 11 & 3.20 \\
\cline { 2 - 5 } & Model two & 27 & 5 & 1.20 \\
\hline
\end{tabular}

\section{Table (2)}

\begin{tabular}{|c|c|c|c|}
\hline Cases & Model & $\begin{array}{l}\text { Lateral } \\
\text { load, } \\
\text { kN }\end{array}$ & $\begin{array}{l}\text { Eigen } \\
\text { value, } \\
\operatorname{Rad}^{2} / \mathrm{sec}^{2}\end{array}$ \\
\hline \multirow{3}{*}{$\begin{array}{l}\text { Case (i) } \\
\text { G+5 }\end{array}$} & Model one & 340 & 83720.21 \\
\hline & Model two & 162 & 166957.11 \\
\hline & Model three & 225 & 337617.12 \\
\hline \multirow{3}{*}{$\begin{array}{l}\text { Case (ii) } \\
\text { G+10 }\end{array}$} & Model one & 182 & 53868.93 \\
\hline & Model two & 180 & 2096.237 \\
\hline & Model three & 120 & 4884.3185 \\
\hline \multirow{2}{*}{$\begin{array}{l}\text { Case (iii) } \\
\text { G+20 }\end{array}$} & Model one & 200 & 540.1131 \\
\hline & Model two & 45 & 1030.7868 \\
\hline
\end{tabular}

\section{CONCLUSIONS}

- The lateral stiffness of the framed structures is enhanced by the infill wall, conversely the presence of apertures within the infill wall would reduce the lateral stiffness

- When considering the infill wall the root displacement of the structure reduces and stiffness of the structure increases. The masonry infill wall is more significant in small structures, but, when the height of the structure increases, the effect of masonry infill wall reduces.

- The displacement is found to be more in the structure where the in-fills are not present. The maximum displacement is found to be $73 \mathrm{~mm}$.

- The lateral load displacement of the framed structures is found to be not regular, it varies because of absence of infill.

\section{REFERENCES}

[1] Alessandra Fiore, Andriana Netti, Pietro Monaco "The Influence of Masonry Infill on the Seismic Behavior of RC Frame Buildings" Engineering structures(2012), volume 44, pp:133-145.

[2] C.V.R Murty, Sudhir.K.Jain "Beneficial Influence of Masonry Infill Walls on Seismic Performance of RC Framed Buildings"12WCEE (2000), pp:1790-1796.

[3] G,C.Monos, V.J.Soulis,J .Thauampteh "The Behavior Of Masonry Assemblages And Masonry In-Filled RC Frames Subjected To Combined Vertical And Horizontal Seismic Type Loading" Advances in engineering software(2012), pp:35-41.

[4] Haroon Rasheed Tamboli, Umesh.N.Karadi "Seismic Analysis Of RC Frame Structure With And Without Masonry Infill Walls" Indian Journal Of Natural Sciences(October 2014) Volume 3, Issue 14, pp:11371148.

[5] Hemant B. Kausik, Durgesh C Rai, Sudhir K Jain (2009) "Effectiveness of Some Strengthening Options for Masonry Infill RC Frames with Open First Storey" Journal Of Structural Engineering (2009) volume 135, issue 8, pp: 212-220.

[6] Jaya Prakash Kadali, M.K.M.V.Rathnam Static Analysis of Multistoreyed RC Buildings By Using Pushover Methodology International Journal for Innovative Research in Science \& Technology Volume1,Issue 8, January 2015 pp113-124.1989.

[7] Kashif Mahmud, Md.Rashadul Islam, Md.Al-Amin "Study The Reinforced Concrete Frame With Brick Masonry Infill Due To Lateral Loads" International Journal Of Civil And Environmental Engineering (2010), Volume 10, Issue 4.

[8] Md. Rashedul Kabir, Debasish Sen, Md. Mashfiqul Islam "Response of multi-storey regular and irregular buildings of identical weight under static and dynamic loading in context of Bangladesh," International journal of Civil and Structural Engineering, Volume 5, No 3, February 2015, pp 252-260.

[9] Md.Irfanullah, Vishwanath.B.Patil "Seismic Evaluation Of RC Framed Buildings With Influence Of Masonry Infill Panel" International Journal Of Recent 
Technology And Engineering (September 2013), Volume2, Issue 4, pp 117-120

[10] Mohammad H. Jinya "Seismic Behavior Of RC Frame Building Is Analyzed By Performing Multi-Model Static And Dynamic Analysis", International Journal Of Research In Engineering And Technology(2014), volume 4, issue 5, pp 411-414.

[11] Mulgund.G, Kulkarni.A.B "Seismic Assessment Of RC Frame Buildings With Brick Masonry In-fills" International Of Advanced Engineering, Science And Technology (2011), Volume 2, Issue 2, pp 140-147.

[12] Niruba, K.V.Boobalakrishnan, K.M.Gopalakrishna "Analysis Of Masonry Infill In A Multi-Storied Building" International Refereed Journal Of Engineering And Science (March 2014), Volume 3, Issue3, pp26-31.

[13]P.B. Kulkarni, Pooja Raut, Nikhil Agarwal "Linear Static Analysis Of Masonry In-Filled RC Frame With And Without Opening Including Open Ground Storey" International Journal Of Innovative Research In Science, Engineering And Technology(2013), Volume 2, Issue 6, pp2215-2223

[14] Shaharbon P.S, Manju P.M "Study On Behavior Of $R C$ Frame With Infill Walls Under Seismic Loads Using E$T A B S^{\prime}$, International Journal Of Civil Engineering And Technology (December 2014), Volume 5, Issue 12,pp:181-187.

[15] Wackchaure M.R, Ped S.P "Earthquake Analysis Of High Rise Buildings With And Without In-Filled Walls" International Journal Of Engineering And Innovative Technology (August 2012), Volume 2, Issue 2, pp 8994.

\section{BIOGRAPHIES}
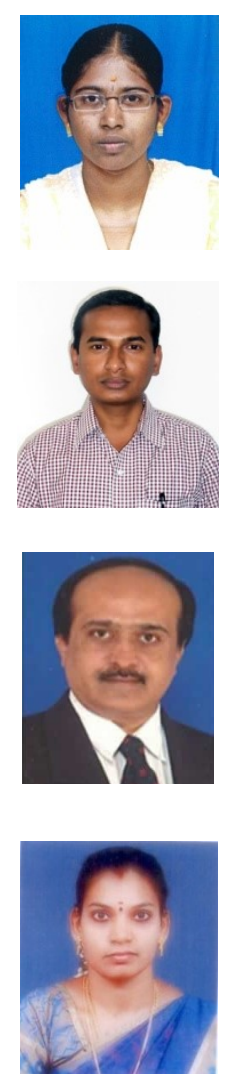

Arulmozhi.N, PG scholar, Deptartment of Civil Engineering, Adhiyamaan College of Engineering, Hosur.

arul.theshark4@gmail.com

+919003965069

Srinivasan.R, Assistant Professor, Dept. Of Civil Engineering Adhiyamaan college of Engineering, Hosur. bksrinivasan8@gmail.com +919952664755

Dr. Suresh Babu .S Dean (Research and development), Head of the Department (Civil Engineering) Adhiyamaan college of Engineering, Hosur. Sunisurp@gmail.com

Jegidha .K.J, Assistant professor

Department of Civil Engineering Adhiyamaan College of Engineering, Hosur. jegirkj@gmail.com $+919444714847$ 